\title{
The Teacher Wars: A History of America's Most Embattled Profession
}

\author{
DANA GOLDSTEIN \\ New York: Doubleday, 2014, 349 p. \\ Ines Perić \\ Sveučilište u Mostaru, Pedagogija \\ University of Mostar, Study of pedagogy \\ Primljeno / Received: 10. XI. 2016.
}

Dana Goldstein je novinarka i spisateljica te dobitnica nekoliko cijenjenih stipendija na području novinarstva. Piše o obrazovanju, ženskim pitanjima, nejednakosti i kaznenom pravosuđu. Njena knjiga „The Teacher Wars“ u kojoj pokriva 175 godina povijesti američkog školstva postala je bestseler New York Timesa što je učinilo Goldstein jednom od najcjenjenijih mladih novinarki u Sjedinjenim Američkim Državama.

Knjiga je podijeljena na uvod, deset poglavlja, epilog, zahvalu, bilješke, odabranu bibliografiju i indeks. Više od petsto primarnih i sekundarnih izvora koje je autorica koristila navedeno je u bilješkama, dok u odabranoj bibliografiji donosi, organizirane prema temi, samo one izvore koje je najviše upotrebljavala što daje vrijedan pregled literature iz ovog područja. U sredini knjige nalaze se i fotografije povijesnih ličnosti i događaja čiju ulogu u razvoju američkog školstva Goldstein opisuje.

U uvodu autorica kao svoju motivaciju za pisanje knjige navodi činjenicu da je poučavanje u javnim školama postalo jedno od najkontroverznijih zanimanja u SAD-u. Nijedna druga profesija nije pod tolikim pritiskom što je donekle i razumljivo zbog dvojake uloge nastavnika: s jedne strane obrazuju i odgajaju našu djecu, dok su s druge ta djeca i budući građani i radnici koji će oblikovati budućnost. Dakle, uloga nastavnika je istovremeno i osobna i politička zbog čega se često naglašava da bi nastavnička profesija trebala biti elitna poput liječničke ili odvjetničke. Međutim, brojevi pokazuju da je potrebno mnogo više nastavnika nego što ih mogu obrazovati elitne visokoškolske ustanove, a, s druge strane, malo je dokaza o tome da bolji učenici u školi kasnije čine i bolje nastavnike. Često se pretpostavlja da su kontroverze vezane za nastavničku profesiju nova pojava, međutim, autorica navodi da Amerikanci još od 19. stoljeća raspravljaju o tome što se treba poučavati u javnim školama, tko treba poučavati, kako obrazovati, zapošljavati, plaćati, evaluirati i otpuštati nastavnike. Jedna od najznačajnijih poruka koje autorica želi prenijeti je da je glavno pitanje o kojem trebamo raspravljati ustvari „kako nastavničko zanimanje učiniti atraktivnim i izazovnim poslom koji bi privlačio inteligentne, kreativne i ambiciozne ljude“ (str. 11). 
Knjiga je kronološki organizirana počevši od 19. stoljeća koje Goldstein opisuje u prvom poglavlju „Učitelji misionari“. Autorica nam kroz živote dvoje povijesnih ličnostiCatharine Beecher i Horace Manna opisuje razvoj nastavničke profesije u tom stoljeću. Beecher je otvorila profesiju ženama iznoseći ideju kako bi neudane žene, za koje se smatralo da ne doprinose produktivno društvu, mogle biti jeftina radna snaga za koju je poučavanje idealan posao budući da je u skladu s njihovom istinskom prirodom. S tim se slagao i Mann koji je, u skladu sa svojim frenološkim uvjerenjima, vjerovao da su žene, iako smanjenog intelektualnog kapaciteta, nesebične i moralno čiste što je odgovaralo potrebama obrazovanja tog doba. Naime, vjerovalo se da se obrazovanje treba više fokusirati na formiranje karaktera, a manje na akademski napredak što je pomagalo održati društveni status quo obrazujući buduće glasače, a ne intelektualce.

U drugom poglavlju „Suzbijena ozlojeđenost“ otkriva se komplicirana veza između feminizma i nastavničke profesije. Naime, 1848. se održala prva nacionalna konferencija za prava žena u Seneca Fallsu koja je rezultirala značajnom „Deklaracijom o pravima i osjećajima“ koja je, među ostalim, govorila i o pravima žena na zaposlenje, jednake plaće i dostupnost obrazovanja. Naime, pristup nastavničkoj profesiji ženama je omogućio da postanu svjesne svojih talenata i da osjete neovisnost, ali i diskriminaciju na radnom mjestu. Žene su prevladavale u nastavničkoj profesiji diljem SAD-a, a ipak je većina novca odlazila muškarcima u profesiji. Zbog toga su žene sve više tražile da im se otvore mogućnosti za karijere u medicini, pravu, politici itd. te su često izražavale i prezir prema nastavničkoj profesiji koja je postala sinonim za skromnost i tradicionalno žensko zanimanje. „Ta mješavina nejednakog, izrazito lokaliziranog obrazovanja nastavnika, niskih plaća, anti- intelektualizma i nedostatka socijalnog prestiža tjerala je ne samo muškarce nego i ambiciozne žene, van učionice“" (str. 44).

Treće poglavlje „Nema izvlačenja, nema zabušavanja“ povezuje nastavničku profesiju sa pokretom za građanska prava. Naime, prije građanskog rata, južne države su se protivile širenju javnih škola, te je obrazovanje bijele djece bilo u rukama obitelji i crkve. Međutim, do 1870. svaka država je bila prisiljena organizirati barem neki oblik javnog obrazovanja sa odvojenim školama za bijelce i crnce što je izazvalo brojne nasilne ispade. „Školske zgrade su se palile, učitelji su bili zlostavljani i ubijani, škole prekinute“ (str. 52). Brojne crnačke škole osnovane u desetljećima nakon Građanskog rata su bile početak dugog razdoblja siromaštva, rasne segregacije, potplaćenih crnih nastavnika i sniženih akademskih očekivanja za crnu djecu koje traje do danas. Tokom sljedećih godina, strukovno obrazovanje je postalo prevladavajuća ideologija ne samo za crne učenike već i za djecu bijelih imigranata iz istočne i južne europe. $\mathrm{Na}$ sjeveru su se bijele učiteljice počele organizirati protiv ovog pristupa.

Četvrto poglavlje „Školske gospođe kao lobisti“ govori o stvaranju sindikata nastavnika i borbi između progresivne pedagogije i školske učinkovitosti. Krajem 19. stoljeća škole u Chicagu su uglavnom pohađala djeca europskih imigranata sa oskudnim znanjem engleskog jezika koji su često napuštali školu kako bi se zaposlili. Obrazovnu politiku je formirao školski odbor čiji su članovi bili gradska elita koja se protivila financiranju „besmislica“ poput pripremanja djece radničke klase za odlazak na koledž ili povećavanja plaća nastavnicama. S druge strane, zalagali su se za davanje više novca za zapošljavanje muških učitelja. To je motiviralo osnivanje Čikaške federacije nastavnika (1897.) čija je namjera bila zalagati se za veće plaće nastavnika i za slobodu u planiranju 
nastave i discipliniranju učenika. Na prijelazu stoljeća, kada žene još nisu imale pravo glasa, organiziranje nastavnica u borbu za veće plaće je bilo šokantno.

Peto poglavlje „Orgija od istrage“ opisuje razdoblje sindikalnog pokreta tijekom I. i II. svjetskog rata. Moralna panika o navodno nedomoljubnim nastavnicima je bila potaknuta međunarodnom ratnom histerijom pa je između 1917. i 1960. nekoliko valova te panike potreslo javne škole i utjecalo na desetine tisuća nastavnika. 1930-ih godina sindikate su preuzeli mladi ljudi od kojih su mnogi bili uključeni u antifašističke organizacije, a koji su radili na rasnoj pravednosti i borili se protiv „umrtvljujuće rutine“ u učionicama. Međutim, sa pojavom Hladnog rata njihove veze sa Komunističkom partijom su postale problematične te je uslijedilo desetljeće antikomunističkih čistki zbog kojih su završile karijere brojnih nastavnika iz javnih škola u New Yorku, a kao posebna smetnja se navodila njihova „nepokornost“ koja „uči učenike da preispituju, umjesto da se obaziru na autoritet" (str. 106). Protjerivanje nastavnika iz škola je poslalo snažnu poruku: oni koji žive izvan glavne političke i kulturne struje nisu dobrodošli u učionicu.

Šesto poglavlje "Jedina važeća putounica iz siromaštva" bavi se rasnim pitanjem američkog obrazovanja. 1954. Vrhovni sud je donio odluku da je školska segregacija neustavna. Međutim, i desetljeće nakon odluke desegregacija je bila zakon, ali ne i stvarnost. Tek kada je Kongres 1964. donio Zakon o građanskim pravima integracija, ma koliko nestalna, je bila postignuta na određeno vrijeme. Najveća promjena za škole je bio Zakon o osnovnom i srednjem obrazovanju predsjednika Johnsona na temelju kojeg se više novca davalo onim državama koje su više brinule za siromašne učenike. Iako i danas postoji konsenzus da su prihodi i obrazovne mogućnosti povezani nikada više nijedna školska reforma nije bila praćena tako snažnom borbom protiv siromaštva. Do 1970. čak su i najveći protivnici prihvatili barem simboličnu školsku desegregaciju u zamjenu za novčana sredstva.

U sedmom poglavlju „I jedni i drugi smo postali militantni“ autorica opisuje razdoblje nacionalnog pokreta za „moć učitelja “ kojeg predvodi United Federation of Teachers (UFT), najveći američki sindikat, i koji postiže veliki politički utjecaj na obrazovanje. Međutim, $\mathrm{u}$ isto vrijeme postalo je jasno da desegregacija nije lijek za sve obrazovne nejednakosti što je uzrokovalo sve veći cinizam prema školama. To je koincidiralo sa objavljivanjem znanstvenog rada Pygmalion in the Classroom (Rosenthal i Jacobson, 1968.) koji je potvrdio općeprihvaćeno mišljenje da bijeli nastavnici često imaju loša mišljenja o intelektu svojih crnih učenika što sprječava njihov uspjeh. U narednim desetljećima nastavnici doživljavaju značajne dobitke u plaći i povlasticama ali, istovremeno, njihova popularnost opada. Naime, činili su se privilegiranima u usporedbi sa obiteljima kojima su služili iako su ostali potplaćeni u usporedbi sa ostatkom visokoobrazovane populacije.

Poglavlje osam „Razbijene iluzije“ stavlja u kontekst neke od najznačajnijih dokumenata američkog školstva počevši od predsjednika Reagana i njegovog „Nation at risk". Taj izvještaj je bio vapaj zbog navodnog mediokriteta američkog školstva koji je žestoko kritizirao američke nastavnike i stvorio osnovu za obrazovni pokret temeljen na nacionalnim standardima i odgovornosti. Unaprjeđenje nastavnika je bio samo jedan od prioriteta postavljenih u izvještaju ali budući da je sve drugo zahtijevalo veća financijska izdavanja fokus je bio na nastavnicima. Iako su brojni stručnjaci žestoko kritizirali „Nation at risk" te su tvrdili da je to „proizvedena kriza“, dugoročno je taj izvještaj prevladao svoje kritičare i poslužio kao temelj svim ostalim programima koji su uslijedili 
poput Clintonovih "Improving america's schools act“ i „Goals 2000“, Bushovog „No Child left behind" i Obaminih "Race to the top" i "The common core“,

Deveto poglavlje „Veliki, mjerljivi ciljevi“ opisuje nastanak i djelovanje jednog od najpopularnijih suvremenih obrazovnih pokreta „Teach for America“. Ideja pokreta je da najbolji studenti, koji se nisu obrazovali za nastavnička zanimanja, nakon završetka studija provedu dvije godine u nastavi i tako doprinesu društvu. Vještine za rad u nastavi dobivaju tijekom ljetne škole čime, kako sami kažu, postaju efikasniji od nastavnika veterana što izaziva brojne kritike. Drugi obrazovni fenomen kojim se autorica bavi u ovom poglavlju je „mjera dodane vrijednosti“ koja otkriva koji nastavnici povisuju ili snižavaju dječje rezultate na testovima. Ta mjera je promijenila američki dijalog o učeničkim postignućima te izazvala kompetitivnost u profesiji kojoj ionako nedostaje suradnje i varanje na testovima, i to od strane nastavnika i ravnatelja. Ovi trendovi su dokazali mudrost „zakona“ kojeg je iznio edukacijski psiholog Donald Campbell: „Što se više neki kvantitativni društveni indikator koristi za društveno odlučivanje, više će biti podložan koruptivnim pritiscima i skloniji iskrivljavanju i korumpiranju društvenih procesa koje bi trebao pratiti“" (str. 209).

Deseto poglavlje „Dopustite mi da koristim ono što znam" govori o potrebi reformiranja obrazovanja kroz osnaživanje nastavnika. Naime, testiranje je dio svakog funkcionalnog obrazovnog sustava, ali prikupljeni podatci ne znače ništa bez sustavnog i planskog unaprjeđenja poučavanja. Goldstein navodi nekoliko primjera dobre prakse i daje konkretne prijedloge za poboljšanje koji bi nastavničko zanimanje učinili privlačnijim. Jedan od njenih najznačajnijih prijedloga se odnosi na korištenje iskustva najboljih nastavnika veterana $\mathrm{i}$ to kroz promatranje njihovog rada, ali i njihovo mentorstvo $\mathrm{i}$ vrednovanje rada mlađih kolega. To bi omogućilo i identificiranje strategija najučinkovitijih nastavnika te njihovu širu primjenu. „Kako bi se unaprijedio prestiž profesije tijekom duljeg perioda važno je da se posao ne doživljava borbenim već osnažujućim i da bude izazovan i stimulativan za odrasle“ (str. 262).

U Epilogu Goldstein rezimira kroz 11 lekcija koje možemo naučiti iz povijesti, a koje nam mogu pomoći u unaprjeđivanju poučavanja danas: 1 . Plaća nastavnika je važna; 2. Stvoriti zajednice prakse; 3. Održati poučavanje zanimljivim; 4. Suočiti se s nasljeđem „normalne škole“ (za obrazovanje nastavnika); 5. Fokusirati se na ravnatelja jednako kao i na nastavnika; 6. Vratiti testove u svoju pravu ulogu- kao dijagnostičke alate; 7. Nastavnici imaju koristi od promatranja jedni drugih kako rade; 8. Privući više muškaraca i osoba crne rase; 9. Završiti sa zastarjelim sindikalnim zaštitama; 10. Dopustiti razvoj alternativnih školskih opcija; 11. Biti realan u vezi s ograničenjima sustava.

Autorica daje zanimljiv i detaljan osvrt na najznačajnije događaje u američkom školstvu u posljednja dva stoljeća, ali, ono što ovu knjigu čini posebno značajnom je da, opisujući američko školstvo, autorica opisuje većinu suvremenih obrazovnih sustava. Mjesto, vrijeme i glavni akteri se razlikuju, ali problemi koji nas tište i načini na koje ih (bezuspješno) pokušavamo riješiti su nam očito zajednički. Zbog toga se ova knjiga ne bi smjela svrstati samo u rubriku nacionalne američke povijesti školstva već koristiti svima kao vodič za rješavanje nagomilanih problema u obrazovanju i unaprjeđivanju rada nastavnika. U vrijeme kada mnogo govorimo o kompetencijama koje su potrebne nastavnicima kao i o najboljim načinima kako izmjeriti napredak učenika (i povezati to dvoje) ova knjiga donosi vrijedne lekcije iz povijesti koje nam mogu poslužiti kao smjernice, ali i spriječiti nas da ponavljamo pogreške koje su već napravljene. 